\title{
МЕДІАОСВІТА
}

Visn. Lviv. Univ., Ser. Zhurn. 2019: 46; 355-363 • DOI: http://dx.doi.org/10.30970/vjo.2019.46.10074

УДК 070-051:005.336.5]:378.091.33-027.22-057.87

\section{ТРЕТІЙ СЕМЕСТР: ОРГАНІЗАЦІЯ СТУДЕНТСЬКОЇ ПРАКТИКИ ЯК ЧИННИК ПРОФЕСІЙНОГО СТАНОВЛЕННЯ МОЛОДОГО ЖУРНАЛІСТА}

\author{
Максим Міщенко \\ Львівський національний університет імені Івана Франка, \\ вул. Генерала Чупринки, 49, Львів, 79044, Україна, \\ e-mail: kafedratpzh@ukr.net \\ https://orcid.org/0000-0003-3107-0426
}

\begin{abstract}
Автор - викладач і журналіст з багаторічним досвідом роботи у мас-медіа - розглядає актуальні питання якісної професійної підготовки студентів під час проходження ними навчально-виробничої практики. Свої судження аргументує думками як авторитетних науковців-теоретиків, так і досвідчених журналістів-практиків. У цьому аспекті йдеться також про досвід плідної співпраці факультету журналістики ЛНУ імені Івана Франка з редакціями всеукраїнських та регіональних ЗМІ.

Ключові слова: майстерність журналіста, студентська практика, «Молодь України», «Ленінська молодь», «Молода Галичина», «День», «Високий Замок», Західний регіональний медіа-центр Міністерства оборони України.

«Як і в інших сферах людської діяльності, в журналістиці кожен проходить певні етапи професійного становлення. Талант же творчого працівника формується поступово, внаслідок насамперед самостійної праці, самостійного досвіду. Не можна навчити писати - цього можна навчитися, повторимо ще раз. Тим паче не можна навчити стати майстром у творчій справі. Майстри народжуються у процесі поєднання природних здібностей, знань, наполегливої праці, терпіння», - таким є початок розділу «Складові журналістської майстерності» хрестоматійного підручника В.Й.Здоровеги «Теорія і методика журналістської творчості» [2, с.26].

Якісна професійна підготовка журналістських кадрів є не лише завданням профільних факультетів вищих навчальних закладів, які готують їх, а й предметом зацікавлення редакцій 3МI, які прагнуть отримати висококваліфікованих спеціалістів. Тому не буде перебільшенням твердити, що студентська практика - ще один, третій семестр кожного навчального року, після якого іспит - можливо, найголовніший
\end{abstract}

(C) Міщенко М., 2019

Наукове керівництво, редагування і рекомендація до друку - проф. Присяжний М. П. 
3-поміж усіх інших - складають не тільки студенти, а й певною мірою їхні університетські викладачі.

«Складністю самого характеру журналістської праці пояснюється складність самої системи підготовки фахівців для цієї сфери духовного виробництва», - підкреслює В. Й. Здоровега [3, с.79]. I зазначає: «Тому надія на редакції, на практику. Може, найбільша складність організації навчального процесу і дозування зусиль самого студента полягає у вмілому поєднанні навчання і посильної участі у практичній журналістській роботі». [3, с. 80].

Дуже часто під час цього третього семестру майбутній журналіст переконується: навіть найменші нюанси журналістського фаху, на яких наголошували на заняттях викладачі і які здавалися не такими вже й суттєвими, підтверджуються об'єктивними вимогами практичної роботи у мас-медіа. Це і практичне застосування різних методів збору інформації, і мовна підготовка, бо ж мова $\epsilon$ не просто інструментом журналістського ремесла, а й засобом мислення, і беззастережно оперативна і вчасна підготовка матеріалів. Недарма I. М. Лубкович цілком слушно констатує: «Після першої ж виробничої практики не така вже й мала частина студентів робить висновок: за час практики я дізнався про журналістику більше, ніж за два роки навчання на факультеті». [4, с.256].

Випускниця факультету журналістики ЛНУ імені І.Франка 2002 року, власний кореспондент телеканалу «1+1» у Херсонській області Олена Ваніна зазначає: «Власне журналістику ми вивчали на практиці. Так, літня практика - найважливіший період навчання. Перший етап - знайти, хто візьме. Домовишся, а потім тебе факультет офіційно скерує. Звичайно, хотілося, щоб тебе поняньчили, знайшли, рекомендували. Але те, що ти сам знайшов і ще й довів, що ти класний і тебе треба взяти на практику, - великий здобуток для студента. I той місяць вартий року теорії». [7, с. 84].

«Попри те, що за совєцьких часів 3МІ, у Львові зокрема, можна було полічити на пальцях, на факультеті дуже мало студентів не мали стосунку ло тієї чи іншої редакції, - свідчить випускник факультету журналістики ЛНУ імені І.Франка 1984 року, лауреат премії Львівської організації НСЖУ імені В. Здоровеги «Сучасність», заступник головного редактора газети «Високий Замок» Ігор Гулик. - Не тому, що там проходили обов'язкову практику, а тому, що мейнстримом вважалося публікуватися на шпальтах «Вільної України», «Ленінської молоді» або ж виходити в ефір Львівського обласного радіо. Тому, як на мене, у нас було значно більше так званих «творчих дипломів», тобто дипломних робіт, написаних на підставі власних доробків випускників факультету. Якщо я помиляюся, то хай мене поправлять компетентніші. Однак досвід головування у ДЕКах наштовхує мене саме на такий висновок» [7, с.60].

У радянські часи існувала чітка й злагоджена система проходження студентами практик. Після першого курсу - тритижнева навчально-ознайомлювальна у багатотиражних газетах, які були на кожному великому підприємстві. Після другого навчально-виробнича у редакціях районних і міськрайонних газет. I тільки після третього - також тривалістю місяць - у редакціях обласних газет, радіо і телебачення, у відділеннях інформагентства РАТАУ (нині Укрінформ). У них же, а також у редакціях республіканських ЗМІ, п'ятикурсники практикувалися два місяці у вересні-жовтні, оскільки у липні-серпні студенти - представники сильної статі проходили завершальний, «полігонний» етап трирічної підготовки на військових кафедрах університетів і складали державний іспит на отримання першого офіцерського звання. 
Відповідною була й кількість та жанрова палітра опублікованих за час практики матеріалів.

Ti, хто працював над творчими дипломами, які передбачали захист власних журналістських матеріалів з теоретичним обгрунтуванням (на превеликий жаль, це тепер майже не практикується), мали можливість протягом місяця під час останнього семестру пройти ще одну практику в редакціях обласних чи республіканських ЗМІ.

Така ступенева схема була цілком логічна, виправдана і доцільна. Як і в будьякій галузі людської діяльності, вивченні наук чи ремесла, практична (як і теоретична під час навчальних семестрів) підготовка здійснювалася за принципом «Від простішого до складнішого». Студент мав право вибору із запропонованих факультетом місць практики, можливість після третього курсу перевірити свої творчі уподобання й орієнтацію на певний різновид мас-медіа (газета, радіо, телебачення, інформагентство).

Щодо суто організаційних аспектів, то тоді не виникало жодних проблем. У радянські часи журналісти вважалися передовими бійцями ідеологічного фронту партії. Тому факультетське скерування на практику було своєрідною «охоронною грамотою», а для очільника ЗМІ - органу партійного чи комсомольського комітету того чи іншого рівня - керівництвом до всілякого сприяння.

Не могло бути й мови, щоб студента не прийняли на практику, як це, на жаль, трапляється тепер. Редактор районної газети за неписаним табелем про ранги був четвертою-п'ятою особою в районі, членом бюро райкому партії, тому під час практики студенти не мали побутових проблем. Їм, наприклад, за вказівкою «згори» надавали окрему кімнату в порожньому на час літніх канікул гуртожитку місцевого профтехучилища. У Києві студенти зі Львова (тоді в Україні було лише два факультети журналістики - у столичному та Львівському університетах), які практикувалися у республіканських партійних газетах, мешкали в гуртожитку видавництва ЦК КПУ «Радянська Україна» (нині «Преса України»), стажери «Молоді України» $\mathrm{i}$ «Комсомольского знамени» - органів ЦК комсомолу України - в гуртожитках університету чи інших столичних вишів, у комітети комсомолу яких також надходила вказівка з головного комсомольського штабу УРСР.

Звертаємо увагу на ці, здавалося б, далеко не першорядні побутові питання, бо сьогодні в організації студентської практики вони стоять вельми гостро. В тім числі, у фінансовому плані. Адже за місце в гуртожитку ПТУ райцентру там, де вони ще залишилися, студентові тепер потрібно платити, а цих видатків йому ніхто не відшкодовуватиме.

Тепер у цьому багатоступеневому процесі втрачено перший і найпростіший для студента щабель: багатонакладних газет нині просто немає. $€$ районні, які ледь животіють, і лише окремі з них перебувають «під крилом» районних рад чи адміністрацій. У їх редакціях до мінімуму скорочено штат працівників і періодичність виходу - раз на тиждень замість колишніх трьох. Якщо зросла кількість полос, то тільки тому, що значне місце на них займає реклама місцевого масштабу, а деякі газети друкують і програму телепередач. 3 огляду на це, другокурсникові вельми проблематично надрукувати протягом місяця 5-6 передбачених програмою практики власних матеріалів, причому не тільки інформаційних, а й аналітичних жанрів.

Водночас збільшилася кількість газет вищого рангу, теле- і радіокомпаній. Але зросли й вимоги до професійної готовності студента до стажування у них. Студент 
тепер в основному сам шукає редакцію ЗМІ і домовляється з її керівництвом про проходження практики. Нерідко його місцем стають щойно створені маловідомі місцеві інтернет-агентства, де вимоги до журналістського професіоналізму явно занижені.

Обласні та регіональні, тим більше всеукраїнські ЗМІ висувають значно вищі критерії. Добре, коли вже після першої ж практики студента запрошують на працю (навіть позаштатну) в ту редакцію, де він тї проходив. Такі прецеденти на факультеті журналістики ЛНУ імені І.Франка непоодинокі. Уже на другому курсі стаціонару (2016/17 навчальний рік) студентка Дар'я Бавзалук працювала кореспондентом найпопулярнішої львівської регіональної газети «Високий Замок». В одному з її номерів у 2017 році було надруковано зразу вісім (!) вагомих за обсягом і тематикою їі матеріалів інформаційних, аналітичних та художньо-публіцистичних жанрів. Великий

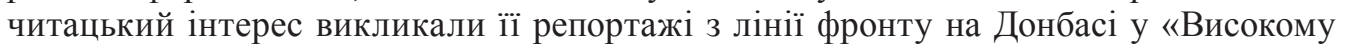
Замку» у березні-квітні того ж року. Одночасно працювала також власкором «України молодої» по Львівській області. А після закінчення другого курсу ще й очолила прес-службу дирекції львівського Форуму видавців. У червні 2017 року була удостоєна премії для молодих журналістів «Перша удача» Львівської організації Національної спілки журналістів України.

Учорашньому першо- чи другокурсникові не так легко практикуватися на радіо чи телебаченні, адже він через об'єктивні причини навчального процесу ще не міг бути досконало обізнаним зі специфікою їх роботи. Йому доводиться терміново опановувати, що таке «підводка» $\mathrm{i}$ «синхрон», особливості співпраці з телеоператором, режисером монтажу, редактором.

3 психологічної точки зору, для студента практика, особливо перша, $є$ неабияким випробуванням. Адже він (для дуже багатьох це стається вперше в житті) 3 помірно структуризованого членства в соціальній групі, яким $€$ членство в студентській академгрупі, потрапляє у ситуацію жорсткого членства в команді професіоналів, чим є редакція ЗМІ. Важливо не тільки те, як зарекомендує себе студент 3 першого ж дня практики у редакційному колективі, а й морально-психологічний клімат у ньому, функціонально-рольові стосунки, взаємоповага як основний принцип внутріредакційного спілкування. Також і ставлення до нього з боку керівника ЗМІ і того журналіста, під кураторство якого він потрапив, як типів лідера соціальної групи (докладніше див.: 5, с.25-71).

Авторитет - якість, яку можна тільки набути. Але, як і університетський викладач, журналіст-професіонал, під чиїм керівництвом практикується студент, володіє нею вже первісно. Добре, якщо такий журналіст пам'ятає, що й сам колись був практикантом, своїх учителів, помилки, які робив і виправляв, те, що справжній майстер неодмінно $є$ і справжнім учителем, який у жодному разі не повинен вдаватися до менторства. «Учень іде вчитися до майстра, - зазначав письменник К.Федін. - Майстер навчає, як уникати помилок, які колись сам робив, а потім навчився їх не робити. У нього теж були свої вчителі, i до того, чому він навчився у них, він додав і свій досвід, Учневі треба не тільки засвоїти знання вчителя, а неодмінно на додачу до них набути власний досвід. Тоді майстерність буде вдосконалюватися, зростати. Наука зупинилася б, якби вчені заспокоїлися на тому, що вони одержали від попередників. Відкриття народжується там, де закінчується знання вчителя і починається нове знання учня». [8, с.349]. 
Студентові не слід сліпо наслідувати свого наставника у зразках, він повинен вчитися у нього методам дослідження, вміння бачити і розуміти. Армійський принцип «Роби, як я» потрібно застосовувати не буквально, а творчо, як цього й вимагає журналістська професія.

Практика буде успішною тоді, коли студент, збагатившись певним досвідом, усвідомлюватиме, що про журналістику він іще мало що не знає. I це спонукатиме його до самовдосконалення і творчих пошукувань.

Написання будь-якого матеріалу, як і журналістика загалом, - це пізнання нового.

Перед інтерв’ю з незнайомою людиною журналіст повинен знати про неї якомога більше. Готуючи кореспонденцію з фермерського господарства чи з трамвайного депо, треба знати про них також якнайдокладніше, як і про фермерство, валовий збір і ціну зернових, надої і собівартість молока, поголів'я худоби, свиней і птиці в регіоні і в Україні загалом; про проблеми міського транспорту і про думки про нього мешканців.

Журналіст не може бути досконало обізнаним у всіх сферах, тому й існує поділ на тематичні відділи, напрями, спеціалізації. Навіть у спортивній журналістиці один добре пише про футбол чи коментує його в ефірі, не знаючи, однак, правил тенісу, інший - про фехтування і гімнастику, майже не розрізняючи стилі плавання, ще хтось - про біатлон і лижні гонки, маючи туманне уявлення про такі зимові види, як фристайл, сноуборд і фігурне катання. Якраз практика допоможе початківцеві визначити коло його професійних уподобань, відтак - напрямки вдосконалення у певній тематиці.

На практиці студент переконується у правильності основоположних у професії журналіста постулатів. Стіл з комп’ютером у редакційному кабінеті - далеко не основне його робоче місце. Неможливо написати нарис чи інтерв'ю, не поспілкувавшись 3 їх героями, звіт чи репортаж - не побувавши особисто на місці події, кореспонденцію - не дослідивши ситуацію на місці. Жодні інтернет-джерела не замінять цього, до того ж, вони самі нерідко містять хибну інформацію. Цього практикант повинен навчитися і у свого редакційного наставника, і на власному досвіді. Як і тому, що робочий день журналіста триває постійно, хіба що з нетривалою паузою на сон.

«Справжній журналіст насамперед - свідок події, - переконаний відомий публіцист, письменник і драматург Генріх Боровик. - Цими подіями він переймається, і про події ці, а точніше, про людей у цих подіях він і хоче розповісти читачеві якнайшвидше, тому що це важливо і це потрібно. Тоді - безпосередність. Тоді - природність і правда» $[1, \mathrm{c.6}]$.

Існує вірогідність, що за свої критичні матеріал студент-практикант зазнаватиме переслідувань з боку об'єктів цієї критики. Особливо, якщо він, як і належить справжньому журналістові, рішуче налаштований на утвердження правди і справедливості. Як актуально звучать слова: «Тепер журналіст на одну чверть складається з уміння написати статтю, а на три чверті - з уміння відстояти те, через що ії написав». [6, с. 14]. А думку цю висловив відомий журналіст і письменник Сергій Львов у своїй книзі «П'ятдесят рядків у номер» більш як півстоліття тому. У цьому контексті йому належить також дуже слушне визначення: «Журналіст - це той, хто пише про те, що знає, а не про те, що від нього хочуть почути». [6, с. 180]. Цих рис студент може набути лише у практичній роботі. 
У цьому контексті вартий уваги багаторічний досвід заслуженого журналіста України Петра Савчака (Львівське ТБ). Практиканта молодших курсів, іще не повністю обізнаного зі специфікою телебачення, він спочатку брав із собою на підготовку свого власного інформсюжету - поспостерігати, як працює на події він сам i його колега-телеоператор, потім - як відбувається монтаж сюжету в студії. Наступне завдання П. Савчак доручав практикантові, але неодмінно сам був присутній на події, готовий будь-якої миті підказати, допомогти. А вже на третє завдання студент вирушав самостійно разом з оператором.

Аналогічні принципи, що базуються на взаємоповазі, готовності майстра допомогти учневі, застосовують у керівництві студентською практикою інші відомі львівські журналісти - Н. Балюк, Г. Вдовиченко, І. Гулик, Ю. Ліщенко, І. Фаріон, Р. Іванчук (газета «Високий Замок»), П. Дворянин (ТРК «Люкс»), В. Павлишин і Р. Цюняк (газета «Спортивка»), С. Ровенчак («Львів-ТБ»), М. Шиманська («ЗІК»). Не дивно, що практика студентів у цих журналістів $€$ особливо продуктивною.

Натомість прикро читати у звітах і щоденниках студентів про практику іноді делікатні, а часом і відверті нарікання на те, що «керівник практики просто відмахнувся від мене», «матеріал повернули без будь-яких пояснень», «завдань жодних не давали», «коли набирала матеріал, мене просто вигнали із-за комп’ютера». Прикметно, що такі випадки трапляються у тих ЗМІ Львівщини, які мають значно нижчий рейтинг, ніж згадані вище популярні видання і ТРК.

У контексті ефективності практики студентів-журналістів доцільно проілюструвати це конкретними прикладами.

У 1970-х роках редактором газети «Молодь України» був світлої пам'яті Ігор Лубченко, а тираж цього популярного видання, що виходило

п'ять разів на тиждень, становив близько 800 тисяч примірників. Він радо приймав на практику, зокрема, і студентів факультету журналістики Львівського університету, всіляко опікувався ними, за умов жорстко визначеного штатного розпису примудрявся влаштовувати їх на ставки стажерів, вирішував питання із житлом. Зустрівши таке ставлення керівника, як і приязність інших штатних і здебільшого молодих за віком працівників, студенти відчували свою відповідальність, сумлінно виконували редакційні завдання, виявляли власну ініціативу, ставали повноправними членами згуртованого редакційного колективу.

Це сприяло стрімкому професійному зростанню студентів-журналістів. Серед колишніх практикантів «Молоді України» Ігоря Лубченка - відомий журналіст, письменник і педагог рівнянин Віктор Мазаний, а світлої пам'яті Володимир Боденчук після закінчення львівського журфаку отримав від «МУ» запрошення на роботу і пройшов там усі щаблі від кореспондента до головного редактора.

Львівська газета «Ленінська молодь» (від 3 квітня 1990 року - «Молода Галичина») у 1970-1990-х роках мала найбільший серед обласних молодіжних газет усього СРСР тираж, який сягав 240 тисяч примірників. Упродовж багатьох років вона була справжньою кузнею талантів. Тут гострили пера майбутні Шевченківські лауреати В. Маняк, В. Яворівський, Я. Гоян, Р. Лубківський, відомі вчені, письменники. Після закінчення III курсу в її редакції пройшов практику майбутній декан факультету журналістики і завідувач кафедри теорії і практики журналістики ЛНУ імені І.Франка М. П. Присяжний, а на четвертому курсі став уже штатним працівником, пройшов до переходу на науково-педагогічну роботу в університеті шлях від кореспондента до 
відповідального секретаря. Там практикувалися нині професор кафедри зарубіжної преси та інформації ЛНУ імені І.Франка М. Г. Житарюк, головний редактор газети «Високий Замок» Н. Балюк, фотограф Президента України М. Марків, шеф-редактор телерадіокомпанії «Люкс» П. Дворянин, власкор УТ-1 у Львові О. Крупник, власкор каналу «1+1» у Херсоні О. Ваніна, багато інших відомих журналістів.

«Двічі - після третього і четвертого курсів - я проходив практику у «Ленінській молоді», - згадує співзасновник і перший генеральний директор інформагентства УНІАН, народний депутат України і Львівської облради перших демократичних скликань, заслужений журналіст України М. І. Батіг. - Обидва рази практикування «за взаємною згодою сторін» - моєю і редактора Петра Путія - затягувалося до кінця серпня і перевиконувалося за обсягом. А на п’ятому курсі, готуючи дипломну роботу на тему «Моральний клімат виробничого колективу», кілька місяців успішно поєднував навчання з роботою стажера «ЛМ». І трирічний зв’язок з редакцією дав свій закономірний результат, мрія здійснилася - перед захистом диплому (у 1981 році - прим. авт.) отримав редакційне запрошення на роботу заввідділом учнівської і студентської молоді. Зрозуміло, що й адаптація молодого спеціаліста у творчому колективі пройшла безболісно, адже тут я вже давно був своїм» [7, с.50]. Додамо, що у грудні 1984 - січні 1993 року М. І. Батіг був редактором цієї газети.

Надзвичайно цікаву і потрібну форму професійної підготовки майбутніх журналістів запровадила редакція газети «День» - Літню школу журналістики. Потрапити туди не так просто - потрібно перемогти у заздалегідь оголошеному конкурсі. Для його лауреатів така практика в авторитетній інтелектуальній газеті є не тільки літньою, а вищою школою практичної журналістики. Вже саме перебування протягом місяця у столиці для студента 3 іншого міста - подія небуденна. До того ж, редакція забезпечує для них житло.

Слухачі школи безпосередньо, зсередини знайомляться 3 редакційною «кухнею». Чи не щодня «День» влаштовує для них зустрічі з провідними політиками, державними діячами, інтелектуалами, послами іноземних держав в Україні. Вислідом їх стають надруковані у «Дні» матеріали авторства тих же слухачів Літньої школи.

У процесі підготовки кваліфікованих журналістів один із важливих чинників не тимчасовий (на час організації практики), а постійний тісний зв'язок «факультет-ЗМІ». Від 2003 року таку співпрацю факультет журналістики ЛНУ імені I. Франка налагодив з тоді прес-центром Західного оперативного командування, а нині Західним регіональним медіа-центром Міністерства оборони України який очолює полковник Олександр Поронюк. До слова, від початку бойових дій на Донбасі він двічі, у 2015 та у 2017 роках у процесі ротації був начальником прес-центру АТО.

3 його ініціативи влітку 2005 року четверо студентів, які тоді закінчили щойно II курс, протягом трьох тижнів працювали кореспондентами прес-центру міжнародних миротворчих навчань за участю 23 країн на Яворівському полігоні за програмою НАТО «Партнерство заради миру». У тім числі, разом з українськими і зарубіжними журналістами брали активну участь у випуску 8 номерів ілюстрованої двомовної (українською та англійською) газети, яка докладно інформувала про перебіг навчань та їх учасників. Зарекомендувавши себе з якнайкращого боку, всі четверо на урочистому закритті навчань отримали сертифікати військових журналістів НАТО.

Редактором газети навчань був прес-офіцер австрійської армії капітан Міхаель Маєрбьок. Улітку наступного, 2006 року з його (вже майора) ініціативи одна із тих 
студенток - Олена Малосняк, яка вільно володіє німецькою мовою, протягом місяця стажувалася у прес-службі Збройних сил Австрії у Відні.

Така співпраця факультету і медіацентру, ефективність якої очевидна, триває і розвивається. Традиційними стали зустрічі студентів і викладачів з прес-офіцерами Збройних Сил України, Національної гвардії, Прикордонних військ, зокрема, які воювали у зоні АТО, а також армій США і Канади, акредитованими у Міжнародному центрі миротворчості та безпеки Національної академії Сухопутних військ імені Гетьмана Петра Сагайдачного на Яворівському полігоні. За сприяння офіцерів медіа-центру полковників Олександра Поронюка, Володимира Скоростецького, Тараса Греня у 2017 році капітан американської армії і водночас магістр зі зв'язків з громадськістю Кейла Крістофер виступила на факультеті з грунтовною лекцією про специфіку роботи служб із зв'язків з громадськістю США, надання достовірної інформації 3 військової тематики, зокрема в умовах бойових дій. У 2018 році фотожурналістка агентства «Франс прес» Гаель Жірб, акредитована в Міністерстві оборони України, провела для студентів майстер-клас про особливості роботи журналіста в умовах війни і представила виставку своїх знімків, зроблених у зоні бойових дій на Донбасі. Тож закономірно, що чимало тем курсових, бакалаврських та магістерських робіт студентів в останні роки присвячено саме військовій журналістиці.

Не можна обійти увагою такий аспект підготовки журналіста, як оволодіння ним майстерності дизайну, макетування і верстки газети. Ця ділянка навчального процесу в останній час послабилася, хоча, як свідчить практика, фах відповідального секретаря, дизайнера, верстальника сьогодні стає ще дефіцитнішим, ніж раніше. Саме під час практики у газеті студент може і повинен опанувати ці ази. Але чи можна вимагати у практиканта зроблених ним самим макетів числа газети, як це передбачено програмою практики? Та й жоден досвідчений викладач зі стажем роботи у газеті не повірить, що студентові молодших курсів довірили самотужки зробити 16 чи й 24 макети шпальт номера такої поважної газети, як «Високий Замок».

Без сумніву, спираючись на набутий досвід, організація студентської практики як чинника професійного становлення молодого журналіста потребує вдосконалення і модернізації. На факультетах журналістики - на лабораторних і практичних заняттях із курсів «Теорія і методика журналістської творчості», «Журналістська майстерність», «Секретаріат сучасної газети», у набутті необхідних навичок на базі факультетських навчальної газети, телерадіостудії, у диференціації скерування студентів у ЗМІ відповідно до рівня знань, професійної та мовної підготовки. У самих 3МI - у зацікавленні в отриманні кваліфікованих кадрів, а отже - у забезпеченні 3 ї боку максимальної продуктивності третього семестру для кожного практиканта. Відтак - у подальшому зміцненні і поглибленні взаємозв'язків і співпраці університетських факультетів та редакцій ЗМІ.

\section{REFERENCES}

1. Боровик Г. А. Предисловие / Генрих Боровик. В кн.: Белят М. Ю. Никарагуа: портрет в черно-красных тонах. Москва : Изд-во Агентства печати Новости. 1987. 392 с., ил.

2. Здоровега В. Й. Теорія і методика журналістської творчості: Підручнник. 2-ге вид., перероб. і допов. / Володимир Здоровега. Львів : ПАІС, 2004. 268 с. 
3. Здоровега В. Й. Про журналістику і журналістів / Володимир Здоровега. Львів: Видавничий центр ЛНУ імені Івана Франка, 2004. 141 с.

4. Лубкович I. М. Чи потрібна журналістові наука про журналістику?/ Ігор Лубкович. Українська журналістика в контексті доби: Матеріали всеукраїнської науково-практичної конференції, 23-24 вересня 2004 року, м. Львів / За ред. С.Костя. Львів, 2004. $472 \mathrm{c.}$.

5. Лубкович І. М. Соціальна психологія масової комунікації / Ігор Лубкович. Львів: ПАIC, 2013. $252 \mathrm{c}$.

6. Львов С. Л. Пятьдесят строк в номер / Сергей Львов. Москва: Молодая гвардия, 1966. $224 \mathrm{c}$.

7. Про далеке і близьке: спогади та роздуми випускників про факультет журналістики ЛНУ ім. І. Франка / [Упоряд.: І. М. Лубкович]. Львів: ПАІС, 2015. 102 с.

8. Федин К. А. Писатель. Искусство. Время / Константин Федин. Москва: Советский писатель, 1957. 524 с.

\title{
THIRD SEMESTER: ORGANIZATION OF STUDENT PRACTICE AS A IMPORTANT FACTOR OF THE PROFESSIONAL DEVELOPMENT OF A YOUNG JOURNALIST
}

\author{
Maksym Mishchenko \\ Ivan Franko National University of Lviv, \\ Generala Chuprynky Str., 49, 79044, Lviv, Ukraine \\ e-mail:kafedratpzh@ukr.net \\ https://orcid.org/0000-0003-3107-0426
}

In the article, the author, who is a teacher and also an experienced journalist with many years of work in media, examines the important aspects of the professional training of students at the faculties of journalism in different universities, in particular during their annual educational and industrial practices in publishers of newspapers, radio, television, news agencies and media centers. He argues his conclusions with the opinions of famous scientists, for example professor V. Zdoroveha, I. Lubkovych), and also journalist-practitioners (M. Batih, I. Gulyk, O. Vanina, H. Borovyk, S. Lvov). Positive examples of cooperation between the faculty of Journalism of the Ivan Franko National University of Lviv and the editorial staff of newspapers and TV, with the Western Regional Media Center of the Ukrainian Defense Ministry (head colonel O. Poronyuk) are presented. The result of such fruitful cooperation is that while studying, a lot of students have a journalist work, even receive certificates of NATO military journalists. The author draws attention to the need to involve experienced journalist-practitioners in teaching students, points the important role in this process of the mentor, the leader. Without the closest relationship between theoretical and practical training it is impossible to prepare a highly professional journalist, the author concludes, calling the period of student practice another fullfledged third semester of the academic year.

Key words: journalist's skill, student practice, «Molod Ukrainy», «Moloda Halychyna», «Den», «Vysokyi Zamok», Western Regional Media Center of the Ukrainian Defense Ministry. 